\title{
Sources of invasions of a northeastern Pacific acorn barnacle, Balanus glandula, in Japan and Argentina
}

\author{
Jonathan Geller ${ }^{1, *, * *}$, Erik E. Sotka ${ }^{2, * *}$, Ryusuke Kado ${ }^{3}$, Stephen R. Palumbi ${ }^{4}$, \\ Evangelina Schwindt ${ }^{5}$ \\ ${ }^{1}$ Moss Landing Marine Laboratories, 8272 Moss Landing Road, Moss Landing, California 95039, USA \\ ${ }^{2}$ Department of Biology and Grice Marine Laboratory, College of Charleston, 205 Fort Johnson Road, Charleston, \\ South Carolina 29412, USA \\ ${ }^{3}$ School of Fisheries Sciences, Kitasato University, Okkirai, Sanriku, Ofunato, Iwate, 022 0101, Japan \\ ${ }^{4}$ Hopkins Marine Station, Stanford University, Pacific Grove, California 93950, USA \\ ${ }^{5}$ Centro Nacional Patagonico (CENPAT-CONICET), Blvd Brown 2825, Puerto Madryn (U9120ACF), Argentina
}

\begin{abstract}
Within years of its introduction, the North American barnacle Balanus glandula Darwin, 1854 became an abundant member of rocky intertidal communities in Japan and Argentina. To determine the regional sources of these invasions, we compared mitochondrial cytochrome c oxidase subunit 1 (COI) and nuclear elongation factor 1 alpha (EF1) genotypes of native and introduced populations. Previously described population structure at these loci in North America conferred geographic information to genotypes. B. glandula from Argentina and southern to central California shared genotypes not found in other native populations. B. glandula from Japan and the northeastern Pacific (Puget Sound and Alaska) were differentiated from other populations by the presence of a nearly fixed nucleotide in EF1 and contained all 3 major haplotype groups of COI. These patterns indicate that sources of B. glandula in Japan and Argentina are largely from Alaska/Puget Sound and California, respectively. The broad similarity of mean seawater temperatures among introduced and native regions may have facilitated these invasions. The presence of greater variation in air temperatures in the invaded than native regions raises the possibility that temperature-related selection may play an important role in the evolution of these invasive populations. We found no evidence of multiple geographic sources of B. glandula in Japan and Argentina, nor of genetic bottlenecks in either invaded region.
\end{abstract}

KEY WORDS: Marine biological invasions · Marine introductions · Invasion sources · Invasion genetics · Balanus glandula $\cdot$ Barnacles

\section{INTRODUCTION}

Biological invasions cause large-scale changes in marine communities (Carlton 1989, 2000, Ruiz et al. 2000, Sax et al. 2005). Several fundamental issues in invasion ecology and management require knowledge of sources. First, do most invasions have single or multiple sources? Multiple sources might facilitate matching of genotypes and new environments, or generate new genotypes, and increase the likelihood of establishment and persistence of a population (Ellstrand \& Schierenbeck 2000, Kolbe et al. 2004, Voisin et al. 2005,
Lavergne \& Molofsky 2007). Second, invaders can adapt to new environments (Grosholz \& Ruiz 2003), but is the adaptability of invaders over shorter (several generations) and longer (10s to $100 \mathrm{~s}$ of generations) timescales dependent on evolutionary history within native environments (cf. Wares et al. 2005)? Third, are invasions self-promoting? Each invasion creates a new potential source woven into a network of global commerce (Carlton 1987, Bagley \& Geller 2000). Answers to these and other related questions require methods to narrow the range of potential source regions from the entire biogeographic range of the species involved. 
Genetic data have been used to suggest probable sources for some marine invasions (McDonald \& Koehn 1988, Geller et al. 1997, Ó Foighil et al. 1998, Bagley \& Geller 2000, Roman \& Palumbi 2004, Zardus \& Hadfield 2005). The inferential power of genetic data depends on specific conditions that include the genetic structure of potential source populations and population genetic processes that cause divergence of introduced populations from their source population(s). We took advantage of recent detailed studies of the genetic structure of a rocky shore barnacle, Balanus glandula, on its native northeastern Pacific coast to investigate sources for invasions in Argentina and Japan. Native B. glandula populations in North America contain profound genetic structure over regional scales (Wares et al. 2001, Sotka et al. 2004, Wares \& Cunningham 2005, E. E. Sotka \& S. R. Palumbi unpubl. data). Alleles of 2 genes (i.e. the alleles designated $\mathrm{C}_{\mathrm{COI}}$ and $\mathrm{C}_{\mathrm{EF} 1}$ ) occur at $100 \%$ frequency at the southernmost location sampled (Huntington Beach, California). These southern allele types decline in frequency to the north until Cape Mendocino. North of Cape Mendocino, $\mathrm{C}_{\mathrm{COI}}$ is maintained at a low frequency ( $\sim 10$ to $20 \%$ ) while $\mathrm{C}_{\mathrm{EF} 1}$ is absent. A recent survey also indicated that native populations within Puget Sound, Washington and Juneau, Alaska are virtually monomorphic for $\mathrm{B}_{\mathrm{EF} 1}$, a northern allele (E. E. Sotka \& S. R. Palumbi unpubl. data). The profound spatial structure of $B$. glandula loci allows for the ready identification of the coastal regions of North America that are sources for introduced B. glandula in Argentina and Japan.

In Argentina, early descriptions of the intertidal rocky shores of the southwestern Atlantic (Ringuelet et al. 1962, Olivier et al. 1966, Penchaszadeh 1973) showed a zonation pattern unusual on temperate coasts for the absence of barnacles. Rock surfaces were covered by the small mytilid bivalves Brachidontes rodriguezii (d'Orbigny, 1842) and Perumytilus purpuratus (Lamarck, 1819). By the end of the 1960s, Balanus glandula was detected on experimental plates within the harbor of Mar del Plata $\left(38^{\circ} \mathrm{S}, 57^{\circ} \mathrm{W}\right.$; Spivak \& L'Hoste 1976, Bastida et al. 1980) and on adjacent rocky shores, where it rapidly became dominant. In contrast, other exotic barnacles in Argentina (Balanus amphitrite and Balanus trigonus) that were introduced in the early 1960s remain at low levels and are confined to protected bay waters (Spivak 2005). After almost 40 yr in the Southwestern Atlantic, B. glandula is now well established along all rocky shores between 37 and $53^{\circ} \mathrm{S}$ (Orensanz et al. 2002, Schwindt 2007).

In Japan, Balanus glandula was found in 2000 for the first time at Sasazaki, Ofunato Bay, on the northeast coast of Japan (Kado 2003). At the time of the discovery, the barnacle had already expanded along the Pacific coast of northern Japan between $38^{\circ} 30^{\prime}$ and $42^{\circ} 40^{\prime} \mathrm{N}$. The abundance of $B$. glandula varied among harbors and ports, but these barnacles effectively monopolized primary space in 3 commercial harbors and achieved a density of $>10000 \mathrm{~m}^{-2}$ on intertidal quaysides. From the shell size of the largest individual collected in 2000 and the known growth rate of this species in North America, Kado (2003) speculated that this specimen was more than 8 yr old, implying a date of first arrival no later than 1992. By 2005, gravid barnacles were present at high densities at Kushiro and Katsurakoi on Hokkaido, the northernmost island of Japan, where it was absent in 2000 (R. Kado pers. obs.). Thus, B. glandula has reached its present northern and western endpoints at $43^{\circ} 00^{\prime} \mathrm{N}$ and $144^{\circ} 26^{\prime} \mathrm{E}$ within $5 \mathrm{yr}$, expanding as quickly as $25 \mathrm{~km} \mathrm{yr}^{-1}$ (Kado \& Nanba, 2006). This is similar to the maximum spread speed estimated for 5 invasive species in Japan (Iwasaki et al. 2004). Southward expansion has not yet been reported.

\section{MATERIALS AND METHODS}

Collection and sequencing of Balanus glandula in North America were described in Sotka et al. (2004). Adult animals were collected from 2001 to 2004 across $\sim 1600 \mathrm{~km}$ of the native range of B. glandula. These locations include Juneau, Alaska $\left(58^{\circ} \mathrm{N}, 134^{\circ} \mathrm{W}\right)$, Puget Sound $\left(48^{\circ} \mathrm{N}, 124^{\circ} \mathrm{W}\right)$, the outer coastlines of Vancouver Island, Washington and Oregon coastlines (latitudes $44^{\circ}$ to $48^{\circ} \mathrm{N}$ : Vancouver Island, Westport Jetty, Cape Meares and Heceta Head in Sotka et al. 2004), central California ( $38^{\circ} \mathrm{N}$; Bodega Marine Laboratory and Pillar Point in Sotka et al. 2004) and southern California $\left(34^{\circ} \mathrm{N}, 118^{\circ} \mathrm{W}\right.$; Huntington Beach). Introduced populations from Argentina were sampled in 2002 at 4 different localities: Mar del Plata $\left(38^{\circ} \mathrm{S}\right.$, $\left.57^{\circ} \mathrm{W}\right)$, Punta Ameghino $\left(42^{\circ} \mathrm{S}, 65^{\circ} \mathrm{W}\right)$, Punta Pardelas $\left(43^{\circ} \mathrm{S}, 64^{\circ} \mathrm{W}\right)$ and Cabo dos Bahías $\left(44^{\circ} \mathrm{S}, 65^{\circ} \mathrm{W}\right) . B$. glandula populations in Japan were collected in 2004 from Ofunato Bay $\left(39^{\circ} \mathrm{N}, 141^{\circ} \mathrm{E}\right)$ and Cape Erimo $\left(42^{\circ} \mathrm{N}, 143^{\circ} \mathrm{E}\right)$. We amplified, sequenced and analyzed $386 \mathrm{bp}$ of mitochondrial cytochrome c oxidase subunit I (COI) and $155 \mathrm{bp}$ of the nuclear-encoded elongation factor 1 alpha (EF1) using methods described in Sotka et al. (2004). A previous phylogenetic analysis (Sotka et al. 2004) had revealed 3 major haplotype groups in both loci. At COI, 2 nucleotide transitions distinguish haplotypes in clades $\mathrm{A}_{\mathrm{COI}}$ from $\mathrm{B}_{\mathrm{COI}}$ (sites 90 and 177, both third codon positions) and a single transition separate haplotypes in clade $\mathrm{A}_{\mathrm{CO}}$ from those in $\mathrm{C}_{\mathrm{COI}}$ (site 315, third codon position). At EF1, a couplet of base pair transversions (sites 107 and 108 in Sotka et al. 2004) separate clades $A_{E F 1}$ and $B_{E F 1}$ while a single transversion separate clades $A_{E F 1}$ and $C_{E F 1}$ (site 105). 
We used these haplotype groupings to characterize barnacles from Argentina and Japan. The native dataset used here was intended for detailed analysis of North American populations beyond the scope of this paper, and has been previously published (Sotka et al. 2004) or will be addressed elsewhere (E. E. Sotka \& S. R. Palumbi unpubl. data).

Nei's $\Pi$ (or the mean number of differences per basepair between populations) and its estimated SD and pairwise values of the genetic divergence measurement $\Phi_{\text {st }}$ were calculated using Arlequin 2.0 on both COI and EF1 sequences (Excoffier et al. 2005). Following Sotka et al. (2004), the model of evolution was $\operatorname{TrN}+\Gamma(\alpha=1.6)$ for COI and F81 for EF1. Statistical significance of $\Phi_{\text {st }}$ was determined from Monte Carlo sampling of 10000 bootstrap replicates, and alpha levels of $\Phi_{\text {st }}$ were adjusted using a Bonferroni correction. Because of low sample size, we treated all Japanese or Argentine barnacles as single populations for $\Phi_{\mathrm{st}}$ analysis at EF1.

We estimated the relative contribution of the native populations to each introduction using the freeware SPAM 3.7 (Statistics Program for Analyzing Mixtures, available at www.genetics.cf.adfg.state.ak.us/software/ spampage.php; Debevec et al. 2000), a program originally developed for mixed stock analysis of fisheries populations. The program employs maximum likelihood and bootstrapping methods to estimate the mixture of baseline populations (i.e. source populations) that has the greatest probability of obtaining the observed genotypic pattern in the target population (i.e. introduced population). The program inputs the haplotype (i.e. A,B,C) frequencies for these analyses. Our native populations were taken to represent the regions where actual source populations may be located. We estimated the relative contribution of native populations and their 95\% nonsymmetric confidence intervals (CI) using 10000 bootstrap replicates. For SPAM 3.7 analysis, non-native samples were pooled to make single Japanese and Argentine populations.

Average monthly seawater temperatures were compiled from the National Oceanographic Data Center (www.nodc.noaa.gov/dsdt/cwtg/npac. html) for North America, the Argentine Oceanographic Data Center (www. hidro.gov.ar/ceado/Ef/Inventar.asp) for Argentina, and the Geological Survey of Hokkaido (www.gsh.pref.hokkaido.jp/ download/temperature_data/sea_temp. html) for Japan. Average monthly air temperatures for native regions were compiled from the National Climate Data Center (www.ncdc.noaa.gov) and for non-native regions from Globalis (http://globalis. gvu.unu.edu).

\section{RESULTS}

Sequences from non-native populations have been deposited in Genbank (COI: EU004281 to EU004414; EF1: EU495994 to EU496087). Japanese barnacles as a group were nearly monomorphic for $\mathrm{B}_{\mathrm{EF} 1}$ and contained all 3 alleles at COI (Table 1, Fig. 1), a pattern similar to that of northern latitudes in the native range (Puget Sound and Juneau, Alaska). A pairwise $\Phi_{\text {st }}$ analysis of COI sequences indicates that Japanese populations were statistically indistinguishable from native populations in Alaska, Puget Sound, and the outer coastline of Vancouver Island, Washington and Oregon, while EF1 allele frequencies in Japan were indistinguishable from Alaskan populations. In contrast, there were significantly elevated values of $\Phi_{\text {st }}$ between Japanese populations and the native populations along central and southern California coastlines at both loci ( $\Phi_{\mathrm{st}}>0.20$; Table 1$)$. A mixed stock analysis of Japanese barnacle genotypes (i.e. individuals sequenced at both EF1 and COI; $\mathrm{n}=37$ ) indicates the majority of the Japanese introduction originated from only Puget Sound, only Alaska or a mix of both locations (mean contribution $~ 0.5$ for each population; $95 \%$ CI for both populations $=0.0$ to 1.0 ), while a smaller percentage may have originated along the outer coastline of Vancouver Island, Washington and Oregon (mean contribution $=0.05 ; 95 \% \mathrm{CI}=0.00$ to 0.22 ).

In contrast with Japanese invaders, Argentine populations contained all 3 major haplotype groups at both loci, a pattern found only in central California (Fig. 1). Pairwise $\Phi_{\text {st }}$ values at both loci were statistically indistinguishable only between Argentine barnacles and central California populations (Table 2). A mixed stock analysis ( $\mathrm{n}=12$ genotypes; Fig. 2) indicates that

Table 1. Locations, allele frequencies and totals, and observed heterozygosity $\mathrm{H}_{\mathrm{O}}$ of EF1. COI: mitochondrial cytochrome oxidase I; EFI: nuclear elongation factor 1a

\begin{tabular}{|c|c|c|c|c|c|c|c|c|c|}
\hline \multirow[t]{2}{*}{ Location } & \multicolumn{4}{|c|}{ — COI alleles } & \multicolumn{5}{|c|}{ EF1 alleles } \\
\hline & A & B & $\mathrm{C}$ & Total & A & B & $\mathrm{C}$ & Total & $\mathrm{H}_{\mathrm{O}}$ \\
\hline Argentina: Mar del Plata & 16 & 5 & 30 & 51 & 5 & 3 & 2 & 10 & 0.600 \\
\hline Argentina: Patagonia & 7 & 5 & 20 & 32 & 3 & 2 & 15 & 20 & 0.400 \\
\hline Japan: Cape Erimo & 21 & 10 & 3 & 34 & 4 & 44 & 0 & 48 & 0.167 \\
\hline Japan: Ofunato Bay & 13 & 4 & 0 & 17 & 0 & 24 & 0 & 24 & 0.000 \\
\hline Alaska & 26 & 6 & 1 & 33 & 2 & 66 & 0 & 68 & 0.059 \\
\hline Puget Sound & 193 & 87 & 24 & 304 & 0 & 70 & 0 & 70 & 0.000 \\
\hline VI/WA/OR & 66 & 24 & 20 & 110 & 28 & 16 & 0 & 44 & 0.364 \\
\hline California: central & 25 & 12 & 56 & 93 & 26 & 6 & 38 & 70 & 0.343 \\
\hline California: south & 0 & 0 & 40 & 40 & 0 & 0 & 30 & 30 & 0.000 \\
\hline Grand total & 367 & 153 & 194 & 714 & 68 & 231 & 85 & 384 & \\
\hline
\end{tabular}



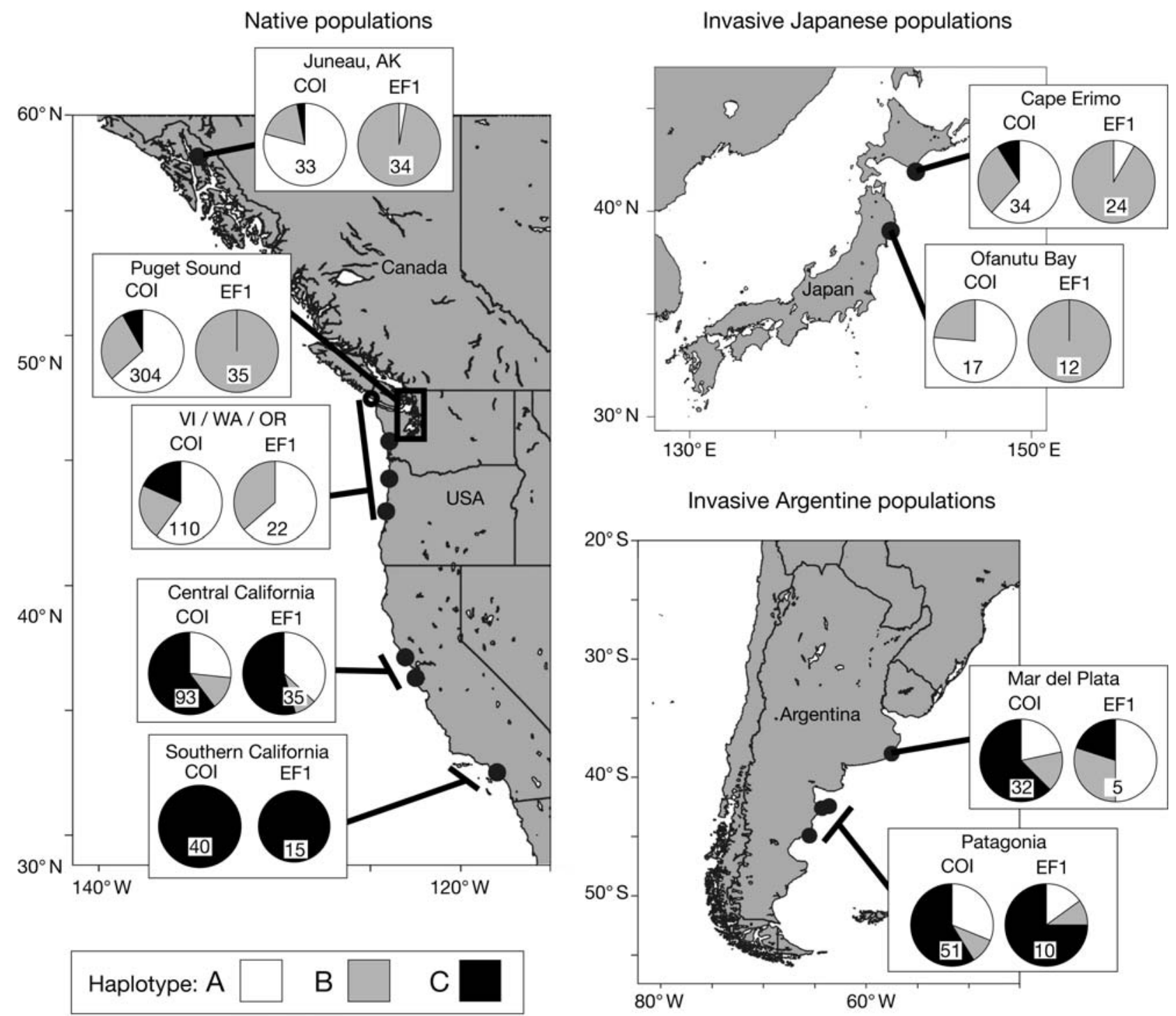

Fig. 1. Balanus glandula. Allele frequencies at 2 genetic loci (cytochrome oxidase I [COI], elongation factor 1 alpha [EF1]) from native and introduced populations. Numbers indicate number of individuals genotyped. AK: Alaska; OR: Oregon; VI: Vancouver Island; WA: Washington State

Table 2. Balanus glandula. $\Phi_{\text {st }}$ analysis of sequence data at 2 loci between invasive (shaded) and native (unshaded) populations. P-values were generated from a distribution of 10000 Monte Carlo replicates and adjusted using a Bonferroni correction ( ${ }^{*}$ significantly different from 0 after correction). Invasive populations were grouped at EF1 because of low sample size

\begin{tabular}{|c|c|c|c|c|c|c|c|}
\hline & \multicolumn{4}{|c|}{ Cytochrome oxidase I } & \multicolumn{3}{|c|}{ Elongation factor 1 alpha } \\
\hline & \multicolumn{2}{|c|}{ Japan } & \multicolumn{2}{|c|}{ Argentina } & & Japan & Argentina \\
\hline & $\begin{array}{c}\text { (Ofunato } \\
\text { Bay) }\end{array}$ & $\begin{array}{l}\text { (Cape } \\
\text { Erimo) }\end{array}$ & $\begin{array}{c}\text { (Mar del } \\
\text { Plata) }\end{array}$ & (Patagonia) & & & \\
\hline Japan (Cape Erimo) & -0.008 & & & & & & \\
\hline Argentina (Mar del Plata) & $0.235^{*}$ & $0.177^{*}$ & & & & & \\
\hline Argentina (Patagonia) & $0.199^{*}$ & $0.155^{*}$ & 0.006 & & Argentina & $0.673^{*}$ & \\
\hline Juneau, Alaska & -0.009 & -0.003 & $0.231^{*}$ & $0.195^{*}$ & Juneau, Alaska & 0.019 & $0.679^{*}$ \\
\hline Puget Sound, Washington & 0.002 & -0.012 & $0.211^{*}$ & $0.188^{*}$ & Puget Sound, Washington & $0.078^{*}$ & $0.720^{*}$ \\
\hline Vancouver Island, WA, OR & 0.023 & -0.003 & $0.132^{*}$ & $0.112^{*}$ & Vancouver Island, WA, OR & $0.423^{*}$ & $0.290^{*}$ \\
\hline Central California & $0.234^{*}$ & $0.180^{*}$ & -0.002 & 0.004 & Central California & $0.603^{*}$ & 0.007 \\
\hline Southern California & $0.624^{*}$ & $0.532^{*}$ & $0.180^{*}$ & $0.194^{*}$ & Southern California & $0.855^{*}$ & $0.263^{*}$ \\
\hline
\end{tabular}


Argentine genotypes $(\mathrm{n}=12)$ originated only from central California (mean contribution $=0.63 ; 95 \% \mathrm{CI}=$ 0.153 to 1.0 ) or a mix of central and southern California (mean contribution $=0.30 ; 95 \% \mathrm{CI}=0$ to 0.65$)$. A small proportion may have originated along the outer coastline of Vancouver Island, Washington and Oregon (mean contribution $=0.07 ; 95 \% \mathrm{CI}=0$ to 0.36 ).

We found no obvious differences in nucleotide diversity at COI between invasive and native populations (Fig. 3). At EF1, the nucleotide diversity of invasive Argentine populations was 5-fold greater than Japanese, Alaskan and Puget Sound populations, and nearly 2-fold greater than the outer coastlines of Vancouver Island, Washington, Oregon and California. These estimates, however, have substantial variance and population differences in diversity were not assessed statistically.

\section{DISCUSSION}

Balanus glandula from the Pacific Northwest and in Japan were differentiated from other native populations by the presence of a fixed nucleotide in EF1 (position 105) and contained all 3 major COI haplotype groups (i.e. $\mathrm{A}_{\mathrm{COI}}, \mathrm{B}_{\mathrm{COI}}$ and $\mathrm{C}_{\mathrm{COI}}$ ). In contrast, B. glandula from Argentinian and Californian populations contained all haplotypes at both EF1 and COI. These genetic results indicate that the source of Japanese $B$. glandula populations is predominantly Alaska, Puget Sound or both, while Argentine invaders originated within California (Figs. 1 \& 2, Table 1).

Many marine invasions have been shown by genetic analyses to have multiple origins (Geller et al. 1997, Zardus \& Hadfield 2005, Voisin et al. 2005), which is not unexpected when major shipping ports are spread within the native range of potential invaders. Interbreeding among barnacles from different sources could

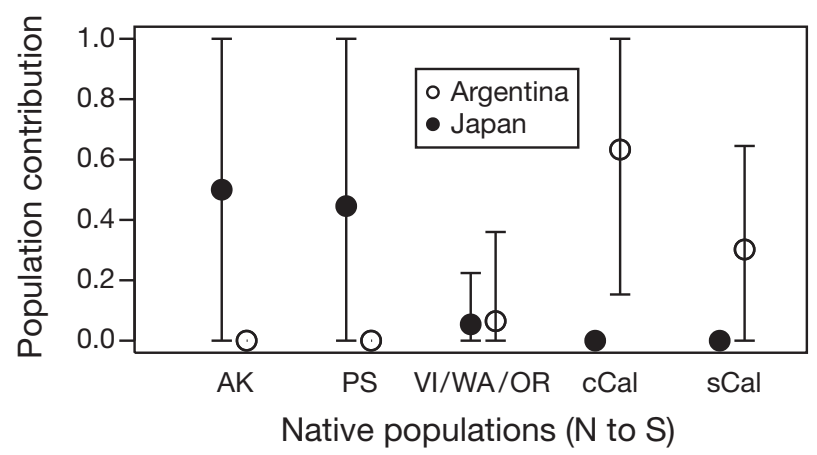

Fig. 2. Balanus glandula. Estimates of the contribution by native populations to invasive populations in Argentina and Japan. Mean estimates of contribution of native populations, and their upper and lower 95\% CI (vertical bars) from 10000 bootstrap replicates were calculated using SPAM 3.7. Abbreviations as in Fig. 1; cCal: central California; PS: Puget Sound; sCal: southern California

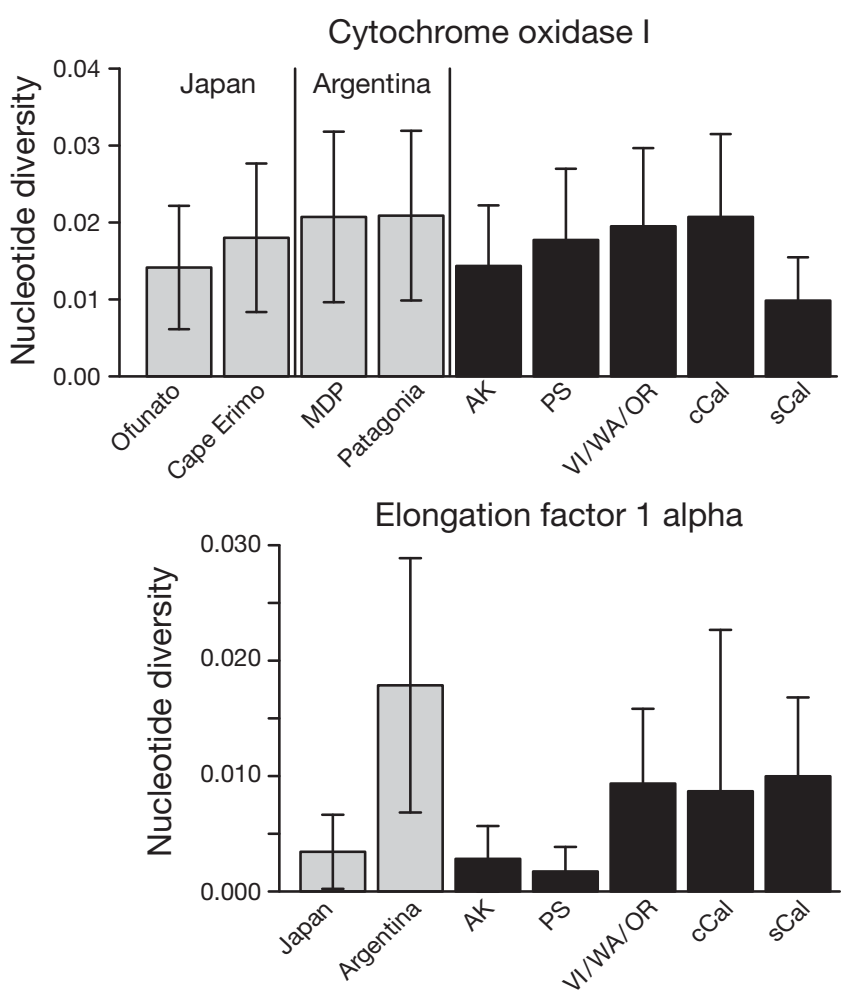

Fig. 3. Balanus glandula. Genetic diversity $( \pm \mathrm{SD})$ at COI and EF1 within native and introduced populations. Note that we grouped Japanese and Argentine populations because of low sample size at Argentina. Abbreviations as in Figs. 1 \& 2; MDP: Mar del Plata

result in novel genotypes that have higher genetic fitness in new environments than native genotypes (Ellstrand \& Schierenbeck 2000, Voisin et al. 2005). However, although we can distinguish regional sources for Balanus glandula invasions, we do not have the ability to distinguish whether it invaded from a single or multiple sources within regions (Fig. 2). This is because of the relatively weak population differentiation within regions (e.g. Puget Sound and Alaska).

The invasions of Balanus glandula in Argentina and Japan have independent sources on the northeastern Pacific shore, and do not indicate perpetuation of invasions at the global level in which established invasions serve as sources for others (Bagley \& Geller 2000). In general, not all invasions will have the same opportunity to found new invasions. Rather, ports in countries with the greatest number of trading partners and volume of shipping will become servers of ballast water (containing propagules of potential invaders) or fouled ships' hulls to the greatest number of non-native sites. Argentina's major export partners are Brazil, the USA, Chile and Germany, while most imports are from Brazil, the USA, China and Germany (www.cia.gov/ library/publications/the-world-factbook/index.html). These countries are the most probable recipients of 
invasive species from Argentina. On a global scale, however, Argentina is not a major trader, with a total of US $\$ 78$ billion (2006) combined imports and exports. Japan, on the other hand, has a larger economy and more trading partners, with US $\$ 1.1$ trillion (2005) combined import and exports. Of the 3 countries hosting B. glandula, the USA has the largest combined trade of US $\$ 2.9$ trillion (2005) and many trading partners. Argentina, then, is not likely to be a major steppingstone for marine invasions, while North America and Japan are more likely to contribute their own biota and pass on invaders to many other regions. We predict that Japan will be a source for new invasions of B. glandula.

The Japanese result confirms the prediction of Kado (2003) that populations in Klawak, Alaska or the Puget Sound ports of Vancouver, Seattle and Tacoma were likely sources for the initial invasion of Balanus glandula because it was initially abundant only in commercial ports such as Ofunato, Hachinohe and Muroran. These ports receive ships laden with timber that embark from those North American ports. An alternative hypothesis, that we now reject, was a central California source, as the Ofunato port also receives oil cokes from San Francisco, Benicia, and Pittsburg (all in San Francisco Bay); our data demonstrate that central California is an improbable source for the genotypes of B. glandula in our Japanese samples.

It is possible that the broad similarity of seawater temperatures in source and target regions may have facilitated these invasion events. (Fig. 4). Warmer sites in southern (average monthly sea surface temperature [SST] of 13.9 to $21.1^{\circ} \mathrm{C}$ ) or central California (10 to $15.6^{\circ} \mathrm{C} ; 18.9^{\circ} \mathrm{C}$ in some sites in San Francisco Bay) were source to warmer sites of invasion in Argentina (southernmost Argentine sites of our study: 8.8 to $13.5^{\circ} \mathrm{C}$; northernmost: 11.0 to $19.0^{\circ} \mathrm{C}$ ). Colder sources in Puget Sound (Seattle: 7.7 to $13.3^{\circ} \mathrm{C}$ ) and/or Alaska (2.2 to $11.1^{\circ} \mathrm{C}$ ) seeded invasions of the colder waters of Japan (present northern limits to Balanus glandula: -0.3 to $19.1^{\circ} \mathrm{C}$; southern limits: 7.7 to $22^{\circ} \mathrm{C}$ ).

At the same time, seasonal variation in air and seawater temperatures along these invaded shores tends to be greater than that experienced by their source populations (Fig. 4). In Japan, there is greater seasonal variation in mean monthly seawater temperatures than is found for any other location along the northeastern Pacific or Argentina. Japanese waters get as warm as Californian waters in the summer, and as cold as Puget Sound and Alaskan waters in the winter. Similarly, Japanese islands experience tremendous seasonal variation in mean monthly air temperatures (north: -10 to $20^{\circ} \mathrm{C}$; south: 0 to $25^{\circ} \mathrm{C}$ ). In Argentina, seawater temperatures are similar to those of central and southern California, while air temperatures tend to be colder in Argentina during the winter (north: 10 to $25^{\circ} \mathrm{C}$; south: 0 to $10^{\circ} \mathrm{C}$ ).

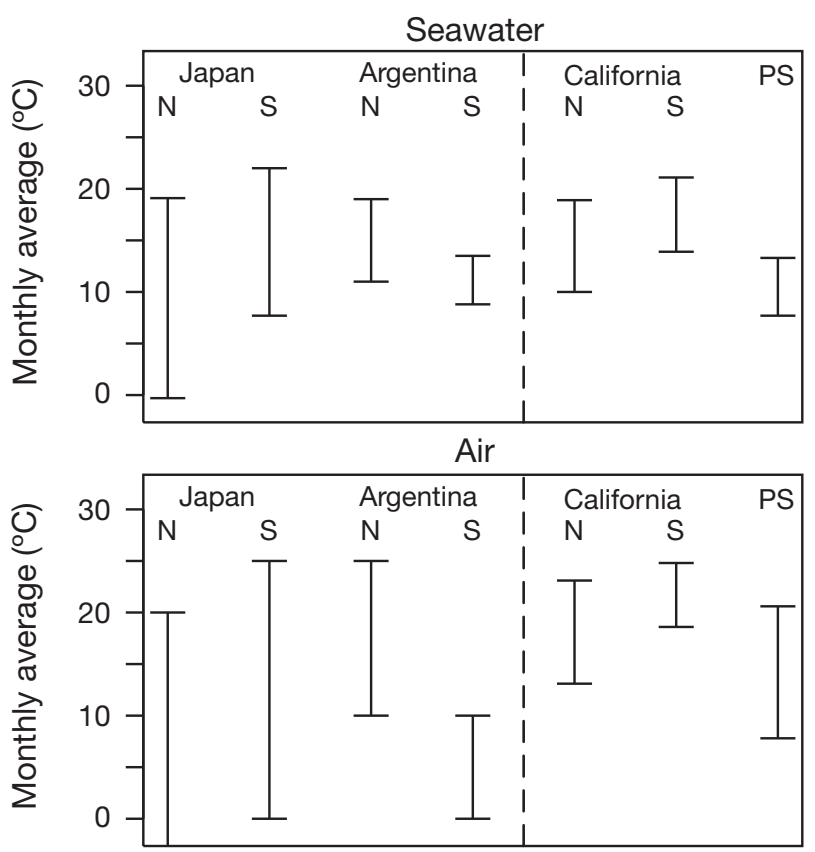

Fig. 4. Average monthly temperatures (max. and min.) of seawater and air for regions in Japan, Argentina, and the native range of Balanus glandula (California and Puget Sound). $\mathrm{N}$ and S: data taken from the northern and southern ends of each region, PS: Puget Sound

These temperature profiles should be interpreted cautiously, given the coarse temporal resolution of the data and the complex of factors that regulate the temperatures experienced by intertidal organisms (Helmuth et al. 2002). However, if ambient conditions are a proxy for the abiotic environment of barnacles, then it appears that both sets of introduced barnacle populations tend to experience greater seasonal variation in temperature than barnacles in their native range. Because of its intertidal habitat, Balanus glandula body temperatures are closely tied to air temperatures during low tides (Harley \& Lopez 2003), and the mortality of these and other temperate barnacles is largely the consequence of this exposure to air (Gosselin \& Qian 1996, Schmidt \& Rand 1999). Thus, these climate data suggest the possibility of air temperature-related selection regimes in Argentina and Japan that appear to differ from native habitats.

There was no obvious decline in genetic diversity of COI and EF1 among nonnative introductions relative to their native sources (Fig. 3). This suggests that a substantial number of invaders (i.e. effective population sizes of $10 \mathrm{~s}$ to $100 \mathrm{~s}$ of individuals at the least) were able to successfully colonize and reproduce in novel habitats. This result agrees with the conclusions of recent reviews (Wares et al. 2005, Roman \& Darling 2007 ) that many invading populations have no or very slight reduction in genetic diversity relative to native populations. 
Acknowledgements. We thank K. Vicknair for collecting samples at Cape Erimo, and A. Strand for discussion. Thanks to R. Burton for hosting a sabbatical visit by J.G. during which this project began. E.S. was partially funded by CONICET, Fundación Antorchas, National Geographic Society (\#780505), FONCYT (PICT \# 20621) and Proyecto ARG 02/018 SP AB-54. J.G. was funded by the National Science Foundation (IOS 0334749), E.E.S. was funded in part by the Andrew W. Mellon Foundation. This is Grice Publication No. 323.

\section{LITERATURE CITED}

Bagley MJ, Geller JB (2000) Microsatellite DNA analysis of native and invading populations of European green crabs. In: Peterson J (ed) Marine bioinvasions: Proceedings of the 1st National Conference. Massachusetts Institute of Technology Sea Grant, Boston, MA, p 241-243

Bastida R, Trivi de Mandri M, Lichtschein de Bastida $V$, Stupak M (1980) Ecological aspects of marine fouling at the Port of Mar del Plata (Argentina). 5th International Congress of Marine Corrosion and Fouling, Madrid, p 229-320

Carlton JT (1987) Patterns of transoceanic marine biological invasions in the Pacific Ocean. Bull Mar Sci 41:452-465

Carlton JT (1989) Man's role in changing the face of the ocean: biological invasions and implications for conservation of nearshore environments. Conserv Biol 3:265-273

Carlton JT (2000) Global change and biological invasions in the oceans. In: Mooney HA, Hobbs, RJ (eds) Invasive species in a changing world. Island Press, Washington, DC, p 31-54

Debevec EM, Gates RB, Masuda M, Pella J, Reynolds J, Seeb LW (2000) SPAM (Version 3.2): Statistics Program for Analyzing Mixtures. J Hered 91:509-510

Ellstrand NC, Schierenbeck KA (2000) Hybridization as a stimulus for the evolution of invasiveness in plants? Proc Natl Acad Sci USA 97:7043-7050

Excoffier L, Laval G, Schneider S (2005) Arlequin (version 3.0): an integrated software package for population genetics data analysis. Evol Bioinform Online 1:47-50

Geller JB, Walton E, Grosholz E, Ruiz G (1997) Cryptic invasions of the crab Carcinus detected by molecular phylogeography. Mol Ecol 6:901-906

Gosselin LA, Qian PY (1996) Early post-settlement mortality of an intertidal barnacle: a critical period for survival. Mar Ecol Prog Ser 135:69-75

Grosholz ED, Ruiz GM (2003) Biological invasions drive size increases in marine and estuarine invertebrates. Ecol Lett 6:700-705

Harley CDG, Lopez JP (2003) The natural history, thermal physiology, and ecological impacts of intertidal mesopredators, Oedoparena spp. (Diptera: Dryomyzidae). Invertebr Biol 122:61-73

Helmuth B, Harley CDG, Halpin PM, O'Donnell M, Hofmann GE, Blanchette CA (2002) Climate change and latitudinal patterns of intertidal thermal stress. Science 298:1015-1101

Iwasaki K, Kinoshita K, Okoshi K, Kimura T and others (2004) Range expansion of non-indigenous marine benthos introduced into Japan through human activities. Bull Plankton Soc Jpn 51:132-144

Kado R (2003) Invasion of Japanese shores by the NE Pacific barnacle Balanus glandula and its ecological and biogeographical impact. Mar Ecol Prog Ser 249:199-206

Kado R, Nanba N (2006) Balanus glandula: a new and potential immigrant barnacle established in northeast coast of Japan from west coast of North America. In: Koike F, Clout MN,
Kawamichi M, De Poorter M, Iwatsuki K (eds) Assessment and control of biological invasion risks. Shoukadoh Book Sellers, Kyoto, Japan and IUCN, Gland, Switzerland, p 210-211

Kolbe JJ, Glor RE, Schettino LR, Lara AC, Larson A, Losos JB (2004) Genetic variation increases during biological invasion by a Cuban lizard. Nature 431:177-181

Lavergne S, Molofsky J (2007) Increased genetic variation and evolutionary potential drive the success of an invasive grass. Proc Natl Acad Sci USA 104:3883-3888

McDonald JH, Koehn RK (1988) The mussels Mytilus galloprovincialis and $M$. trossulus on the Pacific coast of North America. Mar Biol 99:111-118

$>$ Ó Foighil D, Gaffney PM, Wilbur AE, Hilbish TJ (1998) Mitochondrial cytochrome oxidase I gene sequences support an Asian origin for the Portuguese oyster Crassostrea angulata. Mar Biol 131:497-503

Olivier SR, Escofet A, Orensanz JM, Pezzani SE, Turró AM, Turró ME (1966) Contribución al conocimiento de las comunidades bentónicas de Mar del Plata. I. Las costas rocosas entre Playa Grande y Playa Chica. Anales de la Comisión de Investigaciones Científicas de la Provincia de Buenos Aires 7:185-206

- Orensanz JM, Schwindt E, Pastorino G, Bortolus A and others (2002) No longer a pristine confine of the world ocean: a survey of exotic marine species in the southwestern Atlantic. Biol Invasions 4:115-143

Penchaszadeh PE (1973) Ecología de la comunidad del mejillón Brachidontes rodriguezi en el mediolitoral rocoso de Mar del Plata (Argentina): el proceso de recolonización. Physis A 31:51-64

Ringuelet RA, Amor A, Magaldi N, Pallares R (1962) Estudio ecológico de la fauna intercotidal de Puerto Deseado en febrero de 1961 (Santa Cruz, Argentina). Physis A 28:35-52

Roman J, Darling JA (2007) Paradox lost: genetic diversity and the success of aquatic invasions. Trends Ecol Evol 22: $454-464$

Roman J, Palumbi SR (2004) A global invader at home: population structure of the green crab, Carcinus maenas, in Europe. Mol Ecol 13:2891-2898

Ruiz GM, Fofonoff PW, Carlton JT, Wonham MJ, Hines AH (2000) Invasion of coastal marine communities in North America: apparent patterns, processes, and biases. Annu Rev Ecol Syst 31:481-531

Sax DF, Stachowicz JJ, Gaines SD (2005) Species invasions: insights into ecology, evolution, and biogeography. Sinauer Press, Sunderland, MA

Schmidt PS, Rand DM (1999) Intertidal microhabitat and selection at Mpi: interlocus contrasts in the northern acorn barnacle, Semibalanus balanoides. Evolution 53: 135-146

Schwindt E (2007) The invasion of the acorn barnacle Balanus glandula in the south-western Atlantic 40 years later. J Mar Biol Assoc UK 87:1219-1225

Sotka EE, Wares JP, Barth JA, Grosberg RK, Palumbi SR (2004) Strong genetic clines and geographical variation in gene flow in the rocky intertidal barnacle Balanus glandula. Mol Ecol 13:2143-2156

Spivak ED (2005) Los cirripedios litorales (Cirripedia, Thoracica, Balanomorpha) de la región del Río de la Plata y las costas marinas adyacentes. In: Penchaszadeh PE (ed) Invasores invertebrados exóticos en el Río de la Plata y región marina aledaña. EUDEBA, Buenos Aires, p 251-309

Spivak ED, L'Hoste SG (1976) Presencia de cuatro especies de Balanus en la costa de la Provincia de Buenos Aires. Distribución y aspectos ecológicos. Author's edition, Mar del Plata (Argentina)

Voisin M, Engel CR, Viard F (2005) Differential shuffling of 
native genetic diversity across introduced regions in a brown alga: aquaculture vs. maritime traffic effects. Proc Natl Acad Sci USA 102:5432-5437

Wares JP, Cunningham CW (2005) Diversification before the most recent glaciation in Balanus glandula. Biol Bull 208: 60-68

Wares JP, Gaines SD, Cunningham CW (2001) A comparative study of asymmetric migration events across a marine biogeographic boundary. Evolution 55:295-306

Editorial responsibility: Inna Sokolova,

Charlotte, North Carolina, USA
Wares JP, Hughes AR, Grosberg RK (2005) Mechanisms that drive evolutionary change: insights from species introductions and invasions. In: Sax DF, Stachowicz JJ, Gaines SD (eds) Species invasions: insights into ecology, evolution, and biogeography. Sinauer Press, Sunderland, MA, p 229-257

Zardus JD, Hadfield MG (2005) Multiple origins and incursions of the Altantic barnacle Chthamalus proteus in the Pacific. Mol Ecol 14:3719-3733

Submitted: July 6, 2007; Accepted: February 22, 2008 Proofs received from author(s): April 10, 2008 